\title{
Adult onset Still's disease and related renal amyloidosis
}

\author{
Daniel Wendling, Philippe G Humbert, Claude Billerey, Thierry Fest, Jean L Dupond
}

\begin{abstract}
A 57 year old woman presented with clinical and biological features of adult onset Still's disease. A kidney biopsy was performed at the onset of the condition and was found to be normal. Four years later, in view of a nephrotic syndrome, histopathological examination of a new kidney biopsy specimen was made and showed typical amyloid deposition. Renal amyloidosis was suspected in five previously reported cases but demonstrated by kidney biopsy in only two of them. In the present case renal amyloidosis was recorded after disease of four years' duration. The normality of the first renal biopsy specimen suggests the possibility of a direct relation between amyloidosis and adult onset Still's disease.
\end{abstract}

Adult onset Still's disease is a systemic inflammatory illness characterised by a high spiking fever, an evanescent rash, and arthritis. ${ }^{1}$ Association with renal disease has scarcely been reported, however. There are five previous reports of renal amyloidosis but in our case a renal histological examination was made both at the onset of the condition and at the discovery of a nephrotic syndrome four years later.

\section{Case report}

A 57 year old woman was in excellent health until December 1982 but was admitted to hospital in September 1983 for evaluation of a recurrent fever $\left(40^{\circ} \mathrm{C}\right)$ of 10 months' duration associated with a concomitant evanescent macular rash on her trunk and migratory arthralgias. The physical examination showed no hepatosplenomegaly and blood pressure was $110 / 60 \mathrm{mmHg}$.

The white blood cell count was $12 \times 10^{9} / 1$ with $80 \%$ polymorphonuclear cells, $13 \%$ lymphocytes, and 5\% monocytes; haemoglobin was 102 $\mathrm{g} / \mathbf{l}$; and packed cell volume $\mathbf{0} \cdot 27$. The erythrocyte sedimentation rate was $56 \mathrm{~mm} / \mathrm{h}$, fibrinogen $6.15 \mathrm{~g} / \mathrm{l}$, and serum creatinine concentration 79 $\mu \mathrm{mol} / 1$ (normal $60-110$ ). Positive $C$ reactive protein, slightly raised $\mathrm{C} 3$ and $\mathrm{C} 4$ fractions, and normal total complement concentrations were found. Serum protein electrophoresis and immunoelectrophoresis showed only increased $\alpha_{2}$ globulin and normal gammaglobulin concentrations with no abnormal protein spikes. A search for LE cells, antinuclear antibodies, rheumatoid factor, circulating immune complexes, viral blood cultures (including cytomegalovirus, Epstein-Barr virus, herpes, rubella . . .), and antistreptolysins was negative.
Urinary protein excretion was $150 \mathrm{mg} / 24 \mathrm{~h}$ and urine analysis showed $30 \times 10^{3} \mathrm{red}$ blood cells $/ \mathrm{min}$ and less than $10^{3}$ white blood cells $/ \mathrm{min}$ at the time of an attack of the disease.

In an attempt to elucidate the origin of these renal abnormalities the patient underwent a kidney biopsy. It was normal (12 glomeruli examined), with negative immunofluorescence, and neither positive Congo red stain nor positive thioflavine $\mathrm{T}$ stain.

Chest and articular radiographs were normal.

Corticosteroid treatment (prednisolone, $30 \mathrm{mg} /$ day) was given to the patient, who showed clinical and biological improvement. Colchicine treatment ( $1 \mathrm{mg} /$ day) was added 15 months later and the prednisolone dose tapered.

During the following two years clinical control of the disease was fair with this treatment (prednisolone $20 \mathrm{mg} /$ day and colchicine $1 \mathrm{mg} /$ day), with only minor attacks occurring less often than before (every two or three months as compared with twice a month before treatment).

A more severe relapse and biological disturbance prompted re-evaluation in July 1987. Blood pressure was $130 / 70 \mathrm{mmHg}$ without oedema of the legs; physical examination did not show any abnormality. Biological tests disclosed a nephrotic syndrome (proteinuria 5 $\mathrm{g} / 24 \mathrm{~h}$, albuminaemia $28 \mathrm{~g} / \mathrm{l}$ ). Serum creatinine and complement concentrations were normal,

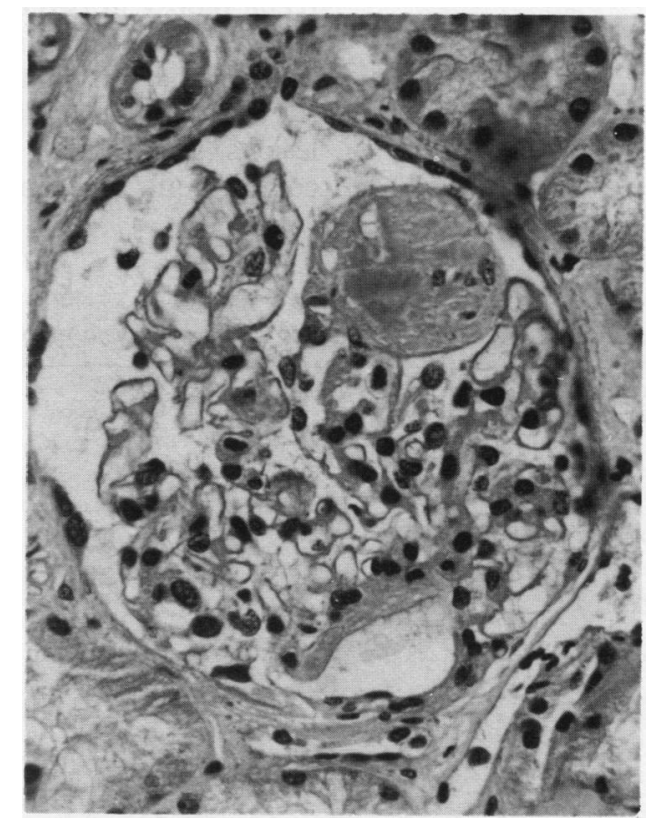

Kidney biopsy specimen showing amyloid deposition leading to complete destruction of some capillary handles (haematoxylin-eosin). 
and urine analysis showed $13 \times 10^{5}$ red blood cells $/ \mathrm{min}$.

In view of a possible amyloidosis a rectal biopsy was carried out but failed to show any amyloid deposits. A renal biopsy was then performed (four years after the first renal evaluation), providing evidence of renal amyloidosis. The deposits were positive with Congo red stain and fluoresced brightly with thioflavine $T$ stain. The deposits were only localised on the glomeruli. Sixteen glomeruli were examined, seven showed deposits described as a thickening of the mesangium, the capillary walls, and afferent artery, leading to complete obstruction of one or several 'capillary handles' (figure). Treatment with potassium permanganate solution blocked the later staining of the sections with Congo red dye, documenting amyloid A protein. Immunofluorescence (IgG, $\operatorname{IgM}, \operatorname{Ig} \mathrm{A}, \mathrm{IgE}, \mathrm{C} 3, \mathrm{C} 4, \mathrm{Clq}$, fibrinogen, $\lambda$ and $x$ chains) was negative. Articular radiographs were unchanged. Six months later a gastrointestinal syndrome with diarrhoea and haematemesis led to a new rectal biopsy being carried out, which provided evidence of amyloid deposits.

\section{Discussion}

This case fulfils the criteria for adult onset Still's disease. ${ }^{2}$ Renal amyloidosis was recorded after disease of four years' duration. The normality of the first renal biopsy specimen suggests the possibility of a relation between adult onset Still's disease and amyloidosis.

Amyloidosis during adult onset Still's disease has been poorly recorded-details of five previous cases have been published (table). ${ }^{3-6}$ In four of these cases renal amyloidosis occurred between seven and 35 years after the onset of the disease. Nephrotic syndrome was the most predominant feature. The absence of hypertension is common. Amyloid deposits have been found during a renal tissue examination ${ }^{35}$ or a rectal biopsy in two other cases.

Adult onset Still's disease associated with amyloidosis has some distinguishing features: prevalence of destructive or ankylosing articular lesions (in 3/4 of the cases), decreased synovial complement concentration in Harrington's case. ${ }^{3}$ The evolution was severe in two patients ${ }^{5}$ with renal failure leading to haemodialysis in one case and death after bowel disease associated with amyloidosis in the other.

The incidence of amyloidosis in the course of adult onset Still's disease still remains to be evaluated. This complication was absent in a number of reported cases. ${ }^{6-9}$ The results of Vigneron et al showed an incidence of $4 \cdot 7 \%{ }^{5}$ Our patient was one of 16 patients $(6.3 \%)$ examined and followed up by us between 1977 and 1987. This incidence is similar to the $7 \cdot 4 \%$ (after a 15 year follow up) found in a large series of patients with juvenile Still's disease. ${ }^{10}$

The rapid deterioration in our patient was more similar to the amyloidosis found in juvenile onset systemic chronic arthritis than that found in the reported cases of adult onset Still's disease.

Amyloidosis should be distinguished from other renal lesions which are occasionally noted in adult onset Still's disease. ${ }^{11-17}$ These consist mainly of mild glomerular lesions, which are probably not related to adult onset Still's disease. ${ }^{11} 16$ The most common renal effect is the modification of urine analysis concomitant with attacks of the disease, such as proteinuria or microscopic or gross haematuria. This was found in four out of the 23 patients studied by Reginato et al. ${ }^{7}$ Cush et al reported the occurrence of nephrolithiasis in two out of 21 cases. $^{6}$ It seems that there is no specific nephropathy associated with adult onset Still's disease.

The pathogenesis of renal amyloidosis has not been elucidated in the reported cases: the potassium permanganate method has not been previously used and serum amyloid substance $A$ was normal in one case. ${ }^{5}$

The drugs taken by the patients did not seem to affect the development of renal amyloidosis, nor did they seem to prevent such a complication, despite fairly good clinical control of the disease with colchicine in our case.

\section{Conclusion}

Renal amyloidosis seems to be an unusual feature of adult onset Still's disease that can occur early, as illustrated by the histological evolution of this case. Such a complication must

Amyloidosis in adult onset Still's disease: Review of published cases

\begin{tabular}{|c|c|c|c|c|c|c|c|c|c|c|c|}
\hline $\begin{array}{l}\text { Author } \\
\text { (ref) }\end{array}$ & $\begin{array}{l}\text { Age of } \\
\text { onset } \\
\text { of the } \\
\text { disease, } \\
\text { sex }\end{array}$ & $\begin{array}{l}\text { Number of } \\
\text { years } \\
\text { before } \\
\text { amyloidosis } \\
\text { onset }\end{array}$ & $\begin{array}{l}\text { Leg } \\
\text { oedema }\end{array}$ & $\begin{array}{l}\text { Arterial } \\
\text { hypertension }\end{array}$ & $\begin{array}{l}\text { Renal } \\
\text { failure }\end{array}$ & $\begin{array}{l}\text { Nephrotic } \\
\text { syndrome }\end{array}$ & Haematuria & $\begin{array}{l}\text { Kidney } \\
\text { biopsy }\end{array}$ & Treatment & Radiographs & Other \\
\hline Harrington $^{3}$ & $\begin{array}{l}59 \\
F\end{array}$ & 35 & + & - & - & + & - & Amyloidosis & $\begin{array}{l}\text { Salicylates, } \\
\text { steroids }\end{array}$ & $\begin{array}{l}\text { Carpal } \\
\text { ankylosis }\end{array}$ & $\begin{array}{l}\text { Decreased } \\
\text { synovial } \\
\text { complement }\end{array}$ \\
\hline Elkon ${ }^{4}$ & $?$ & 10 & ? & $?$ & $?$ & $\begin{array}{c}\text { Protein- } \\
\text { uria }\end{array}$ & $?$ & ND & $?$ & $\begin{array}{l}\text { Articular } \\
\text { destruction }\end{array}$ & $\begin{array}{l}\text { Rectal } \\
\text { biopsy }\end{array}$ \\
\hline \multirow[t]{2}{*}{ Vigneron $^{5}$} & 25 & 19 & - & - & - & + & - & ND & Steroids & - & $\begin{array}{l}\text { Gut } \\
\text { involvement, } \\
\text { death }\end{array}$ \\
\hline & $\begin{array}{l}34 \\
M\end{array}$ & 7 & - & - & - & + & - & Amyloidosis & $\begin{array}{l}\text { Steroids, } \\
\text { antimalarial } \\
\text { drugs, } \\
\text { methisoprinol }\end{array}$ & $\begin{array}{l}\text { Articular } \\
\text { destruction }\end{array}$ & $\begin{array}{c}\text { Renal failure, } \\
\text { dialysis }\end{array}$ \\
\hline Cush $^{6}$ & $\begin{array}{l}16 \\
F\end{array}$ & 40 & $?$ & $?$ & $?$ & $?$ & $?$ & ND & Steroids & $\begin{array}{l}\text { Articular } \\
\text { ankylosis }\end{array}$ & $\begin{array}{l}\text { Hypothyroid, } \\
\text { Sjögren's } \\
\text { syndrome, } \\
\text { psoriasis }\end{array}$ \\
\hline
\end{tabular}


be systematically looked for in a view of its incidence. Differential diagnosis has to be made with other renal lesions that have been described in adult onset Still's disease.

1 Bywaters E G L. Still's disease in the adult. Ann Rhewom Dis 1971; 30: 121-33.

W C. Carpal arthritis with ankylosis in late onset Still's disease. Arthritis Rheum 1976; 19: in late

3 Harrington T M, Moran J J, Davis D E. Amyloidosis in adult onset Still's disease. $\mathcal{F}$ Rheumatol 1981; 8: 833-6.

4 Elkon K B, Hughes G R V, Bywaters E G L, et al. Adult onset Still's disease. Twenty-year follow up and furthe studies of patients with active disease. Arthritis Rheum 1982; 25: 647-54.

5 Vigneron A M, Kaplan G, Labrousse C, Leroux-Robert C René E, Kahn M F. Amylose au cours de la maladie de Still de l'adulte. Ann Med Interne (Paris) 1986; 137: 406-8.

6 Cush J J, Medsaer T A, Christy W C, Herbert D C Cooperstein L A. Adult onset Still's disease. Clinical course and outcome. Arthritis Rheum 1987; 30: 186-94.

7 Reginato A J, Schumacher H R, Baker D J, O'Connor C R Ferreiros J. Adult onset Still's disease: experience in 23 patients and literature review with emphasis on organ failure. Semin Arthritis Rheum 1987; 17: 39-57.
8 Larson E B. Adult onset Still's disease. Evolution of a clinical syndrome and diagnosis, treatment and follow up of 17 patients. Medicine (Baltimore) 1984; 63: 82-91.

9 Wouters J M G W, Reekers P, Van de Putte L B A. Adult onset Still's disease. Disease course and HLA associations. Arthritis Rheum 1986; 29: 415-8.

10 Schnitzer T J, Ansell B M. Amyloidosis in juvenile chronic polyarthritis. Arthritis Rheum 1977; 20 (suppl): 245-52.

11 Hory B, Dupond J L, Deprez P, Leconte des Floris R. Hematuries recidivantes au cours d'une maladie de Still de l'adulte révélée par une péricardite récurrente. Semaine des Hopitaux de Paris 1977; 53: 1715-8.

12 Nicholls K M, Fairley K F, Dowling J P, Kincaid-Smith P. The clinical course of mesangial IgA associated nephropathy in adults. $O$ F Med $1984 ; 210: 227-50$.

13 Bujak J S, Aptekar R G, Decker J L, Wolff S M. Juvenile rheumatoid arthritis presenting in the adult as fever of rheumatoid arthritis presenting in the adult as fever

14 Kemp K Von, Demaen F, Huybrechts M, Verbruggen L. Hematuria as presenting sign in Wissler-Fanconi syndrome. f Rheumatol 1987; 14: 145-6.

15 Mallet H, Dupond J L, Dalphin J C, Humbert Ph, Leconte des Floris R. Maladie de Still de l'adulte associé à une glomérulonéphrite à IgA. A propos d'un cas. Rev Med Interne 1985; 6: 565-7.

16 Caroit M, Mathieu M, Kahn M F, de Seze S. Maladie de Still de l'adulte et syndrome de Wissler-Fanconi. Rev Rhum Mal Osteoartic 1973; 40: 1-8.

17 Wendling D, Humbert P, Hory B, Blanc D, Dupond J L, Guidet $M$. Le rein de la maladie de Still de l'adulte. Reo Rhum Mal Osteoartic 1989; 56: 325-7. 